\title{
SELF-REPORTED TINNITUS HANDICAP IN INDIVIDUALS WITH AUDITORY NEUROPATHY SPECTRUM DISORDER
}

\author{
P. Prashanth Prabhu, P. Sneha
}

Department of Audiology, All India Institute of Speech and Hearing, Manasagangotri, Mysore, India

Corresponding author: P. Prashanth Prabhu, Department of Audiology, All India Institute of Speech and Hearing, Manasagangotri, Mysore India, e-mail: prashanth.audio@gmail.com

\begin{abstract}
Background: Tinnitus is one of the symptoms reported by individuals with auditory neuropathy spectrum disorders (ANSD). There are no studies examining the handicap caused by tinnitus in these cases. The study administered the 'Self report tinnitus handicap questionnaire' (SR-THQ) and estimated the pitch and loudness of tinnitus in individuals with ANSD.
\end{abstract}

Material and methods: SR-THQ was administered to 30 individuals diagnosed with ANSD. The participants subjectively rated their tinnitus pitch, loudness, and severity. Tinnitus was also determined by matching pitch and loudness in 25 of these individuals.

Results: The mean percentage tinnitus handicap in individuals with ANSD was 59.3\%. The majority of the participants reported their tinnitus frequency to be low-pitched, moderately loud, and the severity ranged from moderate to severe. There was a weak or moderately negative correlation between SR-THQ scores and tinnitus pitch and loudness.

Conclusions: Tinnitus can cause emotional problems and affect daily life in individuals with ANSD. Thus, clinically, one should attempt to manage tinnitus in individuals with ANSD.

Keywords: auditory neuropathy spectrum disorder • tinnitus • self-reported handicap • pitch and loudness

\section{TINNITUS REPORTADO POR LAS PERSONAS CON NEUROPATÍA AUDITIVA}

\begin{abstract}
Resumen
Introducción: El tinnitus es uno de los síntomas reportados por las personas con trastornos del espectro de neuropatía auditiva (ANSD en inglés). Hasta la fecha de hoy no se han realizado los estudios en cuanto a los trastornos provocados por el tinnitus en estos casos. En el presente estudio se ha aplicado el cuestionario Self report tinnitus handicap questionnaire (SR-THQ). El objetivo ha sido también el de evaluar el tono y el volumen del tinnitus en las personas con ANSD.
\end{abstract}

Materiales y métodos: El cuestionario fue completado por 30 personas diagnosticadas con el ANSD. Los participantes de la prueba han hecho una valoración subjetiva del tono, volumen y la escala de la molestia del tinnitus. Además, 25 pacientes entre los que participaron en la prueba, fueron evaluados para comprobar la correlación del tono y el volumen del tinnitus.

Resultados: La prevalencia media del tinnitus en las personas con el ANSD ha sido de 59,3\%. La mayor parte de los participantes de la prueba reportó el tinnitus de frecuencias bajas, de mediano volumen, y de molestia de media hasta muy grande. La correlación entre los resultados del cuestionario y el tono y volumen del tinnitus ha sido ligeramente o moderadamente negativa.

Conclusiones: El tinnitus puede causar problemas emocionales y afectar la vida diaria de personas con ANSD. Por este motivo, desde el punto de vista clínico, se debe tratar de eliminar el tinnitus en las personas con ANSD.

Palabras clave: trastornos del espectro de la neuropatía auditiva • tinnitus • disfunción reportada por el paciente • tono y volumen

\section{УШНОЙ ШУМ, НА КОТОРЫЙ ЖАЛОВАЛИСЬ ЛЮДИ СО СЛУХОВОЙ НЕЙРОПАТИЕЙ}

\section{Изложение}

Введение: Ушной шум - это один из симптомов, на который жалуются люди с расстройствами спектра слуховой нейропатии (ANSD). До сих пор в этих случаях не велись работы, уделяющие внимание расстройствам, 
вызванным ушным шумом. В настоящей работе применено Self report tinnitus handicap questionnaire (SR-THQ). Целью являлась также оценка высоты и громкости шума у людей с ANSD.

Материал и методы: Анкета была выполнена 30 пациентами с диагностированной ANSD. Участники исследования субъективно оценивали высоту, громкость и состояние неудобства в связи с ушным шумом. Дополнительно исследовано 25 пациентов среди людей, которые участвовали в исследовании, которое концентрировалось на корреляции высоты и громкости ушного шума.

Результаты: Средний процент наличия ушного шума у людей с ANSD составлял 59,3\%. Большинство участвующих жаловались на ушной шум с частотой ниской и средней громкости, со средней и очень большой степенью неудобства. Корреляция между результатами анкеты, высотой и громкостью ушного шума была слабо или умеренно отрицательной.

Выводы: Ушной шум может вызывать эмоциональные проблемы и влиять на ежедневную жизнь людей с ANSD.

Ключевые слова: расстройтсва спектра слуховой нейропатии • ушной шум • расстройство • на которое жалуется пациент • высоста и громкость

\section{SZUMY USZNE ZGŁASZANE PRZEZ OSOBY Z NEUROPATIĄ SŁUCHOWA}

\section{Streszczenie}

Wprowadzenie: Szumy uszne są jednym z objawów zgłaszanych przez osoby z zaburzeniami spektrum neuropatii słuchowej (ANSD). Dotąd nie prowadzono prac pod kątem zaburzeń spowodowanych szumami usznymi w takich przypadkach. W niniejszej pracy zastosowano Self report tinnitus handicap questionnaire (SR-THQ). Celem była również ocena wysokości i głośności szumów u osób z ANSD.

Materiał i metody: Kwestionariusz został wypełniony przez 30 osób ze zdiagnozowaną ANSD. Uczestnicy badania subiektywnie oceniali wysokość, głośność i stan uciążliwości szumów usznych. Dodatkowo zbadano 25 pacjentów spośród osób biorących udział w badaniu pod kątem korelacji wysokości i głośności szumów usznych.

Wyniki: Średni odsetek występowania szumów usznych u osób z ANSD wynosił 59,3\%. Większość uczestników zgłaszała, że występują u nich szumy uszne o częstotliwościach niskich, średnio głośnych, o uciążliwości od średniej do bardzo dużej. Korelacja pomiędzy wynikami kwestionariusza oraz wysokością i głośnością szumów usznych była słabo lub umiarkowanie ujemna.

Wnioski: Szumy uszne mogą powodować problemy emocjonalne i wpływać na życie codzienne osób z ANSD. Dlatego, z klinicznego punktu widzenia, należy dążyć do wyeliminowania szumów usznych u osób z ANSD.

Słowa kluczowe: zaburzenia spektrum neuropatii słuchowej • szumy uszne • wada zgłoszona przez pacjenta • wysokość i głośność

\section{Background}

Auditory neuropathy spectrum disorder (ANSD) is defined as a retrocochlear disorder in which a patient's outer hair cells are normal (in terms of otoacoustic emissions/ cochlear microphonics) but an absent/abnormal auditory brainstem response (ABR) [1-5]. The cause of ANSD might be at the level of the inner hair cells, junction of the spiral ganglion cells, and/or the auditory nerve itself $[6,7]$. ANSD is diagnosed based on multiple behavioural and electrophysiologic tests (such as ABR, OAE, acoustic reflexes, word recognition scores, speech perception in noise) [8]. Among the variety of symptoms reported by individuals with auditory neuropathy spectrum disorder, tinnitus is common [9-11].

Among the hearing-impaired population, the reported incidence of ANSD varies from $11 \%$ to $0.54 \%[4,9,12]$. Chandan et al. [10] determined the prevalence of tinnitus in individuals with ANSD was 67\%. Prabhu et al. [11] reported that $83 \%$ ( 25 out of 30 ) of the participants in their study reported tinnitus. Kumar and Jayaram [9] reported that
$50 \%$ of the auditory dys-synchrony population had bilateral tinnitus. Thus, the literature suggests that the majority of individuals with auditory neuropathy spectrum disorder report reduced hearing sensitivity, difficulty in understanding speech, and tinnitus [9-11].

Tinnitus is the perception of sound in the absence of an external sound source [13]. In general, tinnitus occurs in approximately 10 to $15 \%$ of adults. The prevalence rate increases with age and more men than women report tinnitus. In 1 to $2 \%$ of cases, tinnitus is severe enough to significantly impair daily life [14]. Clinical depression has been reported in $20-60 \%$ of tinnitus patients $[15,16]$. Approximately $20 \%$ of tinnitus patients experience the disorder to a degree that their quality of well-being and productivity are impaired [17]. Tinnitus is a subjective phenomenon, so clinical assessment must rely on subjective assessment methods such as questionnaires. Questionnaires can be administered either in writing or verbally. Self-reported measures are a standard way of determining the severity of tinnitus distress. There a number of common questionnaires to assess tinnitus distress such as the Tinnitus 
Handicap Questionnaire (THQ) [18]; the Tinnitus Reaction Questionnaire (TRQ) [19]; the Tinnitus Handicap Inventory (THI) [20]; the Self Report Tinnitus Handicap questionnaire (SR-THQ) [21], and the Tinnitus Questionnaire (TQ) [22].

Of the tinnitus questionnaires available, it is essential to select one that has been documented for validity and reliability. In the environment of a busy clinical practice, a self-report measure must be brief, have a simple response format, and be easy to score and interpret. The self-report tinnitus handicap questionnaire (SR-THQ, Appendix A) is standardized for the Indian population and meets each of the practical considerations [21]. Furthermore, although some well-established scales evaluate the physical, emotional, and social consequences of tinnitus, the SR-THQ response categories reflect alternative reactions. There are 3 subscales: the functional subscale, the emotional subscale, and the catastrophic subscale. The SR-THQ has good internal consistency and reliability for the total scale $(\alpha=0.93)$, and performs adequately for the functional $(\alpha=0.86)$, emotional ( $\alpha=0.87)$, and catastrophic subscales $(\alpha=0.68)$ [21].

In individuals with ANSD, the focus has always been on symptoms like difficulty understanding speech in noise and speech perception difficulties, while symptoms like tinnitus are ignored. There are no studies in the literature which provide information about the effects of tinnitus on a person's functioning in daily life or emotional distress in individuals with ANSD. In the present study, the aim of administering the SR-THQ was to estimate the effect of tinnitus on a person's functioning and the related emotional and catastrophic effects in individuals with ANSD. It was also attempted to estimate the pitch, loudness, and severity of tinnitus using a subjective rating scale and to correlate those measures with the tinnitus estimates derived from SR-THQ scores.

\section{Material and methods}

The study consisted of 30 individuals ( 12 male, 18 female) who were diagnosed as having ANSD. The mean age was 17.6 years for males and 19.4 for females. ANSD was clinically diagnosed based on the criteria recommended by Starr et al. [23]. All participants had preserved cochlear amplification, reflected by the presence of transient evoked otoacoustic emissions and/or cochlear microphonics; abnormal auditory nerve responses as indicated by absent or severely abnormal auditory brainstem responses; and normal otologic and tympanometric findings with absent acoustic reflexes. A detailed neurological examination by a neurologist was carried out on all individuals to rule out any space-occupying lesion; this assessment included the result of radiologic investigations such as CT/MRI.

\section{Procedure}

All participants were tested with calibrated audiometers in sound-treated rooms. Pure-tone audiometry was done using the modified Hughson and Westlake procedure [24]. Speech identification testing was done with monitored live voice presentation of phonemically balanced monosyllables or a phonemically balanced word list in Kannada [25] at $40 \mathrm{dBSL}$ (re speech recognition threshold). Immittance evaluation (tympanometry and acoustic reflex threshold testing) for a $226-\mathrm{Hz}$ probe tone was carried out with a calibrated middle ear analyzer (GSI Tympstar v.2.0). Transient evoked otoacoustic emissions were measured using a calibrated OAE analyzer (ILO v6 DP Echoport) and auditory brainstem response testing was done using a Biologic Navigator or IHS Smart EP (Version 3140) evoked potential system. An identical protocol was used to test all patients.

TEOAEs were recorded from all participants while they were seated in a sound treated room using the Otodynamics Echoport. TEOAEs were acquired using the non-linear protocol with two trains of click stimuli $(80 \mu$ s rectangular clicks) at $80 \mathrm{~dB}$ peak SPL. The responses to the click trains were stored and averaged in two $20 \mathrm{~ms}$ buffers. A total of 260 click trains $(260 \times 4=1040$ clicks $)$ were presented at a rate of 50/s for each measurement run. Stable probe placement in the ear was ensured by requiring that the percent stimulus stability (the average correlation between the response waveforms at the beginning and end of each recording) remained above $90 \%$ throughout the whole recording session. All participants completed the TEOAE recording procedure and had SNRs of more than $6 \mathrm{~dB}$. ABR recordings was carried out using a click stimulus with insert phones (ER-3A) positioned in a subject's ear canals and disposable $\mathrm{Ag} / \mathrm{AgCl}$ surface electrodes were placed at the vertex $(\mathrm{Cz})$ (non-inverting) and over the mastoid of their test ear (M1 or M2) (inverting) and non-test ear (M2 or M1 as ground). Electrode impedances were maintained at less than $2 \mathrm{k} \Omega$ each. ABR waveforms were first recorded by stimulating each ear with click stimuli at 90 $\mathrm{dB}$ nHL at 11.1 clicks/s and at 90.1 clicks/s using both rarefaction and condensation polarities (both with two traces per ear). All ABR signals were amplified 100,000 times, recorded for $10.24 \mathrm{~ms}$ post-stimulus, averaged over 2048 samples, filtered from $100-3000 \mathrm{~Hz}$, and the non-test ear was masked with white noise at the test ear stimulus level minus $40 \mathrm{~dB}$. In a few of the participants a long-ringing $\mathrm{CM}$ was clearly recorded during ABR recordings. Auditory brainstem recording was done twice to ensure reproducibility of waveforms.

\section{Administration of SR-THQ}

The 25 questions of the SR-THQ (Appendix A) were administered to all participants. They were asked to answer 'yes', 'sometimes', or 'no'. The questions in SR-THQ are grouped under three subscales: functional, emotional, and catastrophic. The functional subscale has 17 questions, the emotional subscale 6 questions, and the catastrophic subscale 2 questions. Each 'yes' response was awarded 4 points, 'sometimes' responses were awarded 2 points, and 'no' responses were awarded 0 points. The total of the scores obtained from SR-THQ is 100 . In addition, the scores obtained from all three SR-THQ subscales were divided by the maximum possible scores for each scale and converted to percentages for interpretation.

\section{Subjective tinnitus rating}

In addition to the handicap questionnaire, three subjective rating scales were also added to the SR-THQ. In the subjective tinnitus pitch rating (TPR) scale, participants were instructed to indicate the pitch of their tinnitus on 
a scale of 1 to 10 , i.e., ' 1 ' being very low pitched and ' 10 ' being very high pitched. In the subjective tinnitus loudness rating (TLR) scale, participants were asked to indicate the loudness of their tinnitus on a scale of 1 to 10 , i.e. ' 1 ' being very soft and '10' being very loud. In the subjective tinnitus severity rating scale, participants were instructed to indicate the overall severity of their tinnitus based on pitch, loudness, and duration of their tinnitus i.e. ' 1 ' being minimally severe and ' 10 ' being highly severe.

\section{Objective tinnitus evaluation}

Objective information about the characteristics of tinnitus (pitch and loudness) was obtained from 25 participants. The other 5 participants were not considered for objective tinnitus evaluation as it was not possible to test them because of time constraints, so they completed only the SR-THQ questionnaire. For unilateral tinnitus, the ear with tinnitus was chosen as the test ear. For binaural tinnitus with equal tinnitus loudness, the right ear was chosen. For binaural tinnitus with unequal tinnitus loudness, the ear with the loudest tinnitus was chosen. For pitch matching, frequencies were tested between 125 and 8000 $\mathrm{Hz}$. For the frequency at which the pitch was matched by the individuals, tinnitus loudness was also estimated. For loudness matching, the same procedure as described for pitch matching was employed to decide the test ear. The test tone was below the subject's threshold and only an ascending series of intensity levels was employed to minimize residual inhibition. The sound level was increased in small steps until the subject reported that the external tone was just equal to the loudness of their tinnitus.

\section{Ethical considerations}

All testing procedures done used non-invasive techniques which adhered to conditions set by the ethics approval committee of the All India Institute of Speech and Hearing, Mysore. All test procedures were explained to the patients and their family members before testing and informed consent was received from all patients or their family members for participating in the study.

\section{Results}

\section{Results of SR-THQ}

The results of SR-THQ administered on all participants showed that the mean total score on SR-THQ was 59.3 $(\mathrm{SD}=12.4)$. The mean score for the functional sub scale was $37.0(\mathrm{SD}=10.5)$, emotional subscale was $18.9(\mathrm{SD}=4.2)$, and catastrophic subscale was $3.4(\mathrm{SD}=2.1)$. The mean percentage handicap on the functional scale was $54.5 \%$ $(\mathrm{SD}=17.4)$, emotional scale was $78.7 \%(\mathrm{SD}=26.7)$, and catastrophic scale was $42 \%(\mathrm{SD}=15.4)$. The results obtained for the subscales are depicted in Figure 1.

\section{Results of subjective tinnitus rating}

The participants of the study were also asked to rate their tinnitus in terms of its pitch, loudness, and severity on a scale of 1 to 10 . The results show that, in terms of pitch, $56.7 \%$ (17 out of 30 ) rated the pitch as low (rating of $1-3$ ), $33.3 \%$ (10 out of 30 ) rated it as high (rating of 7-10), and

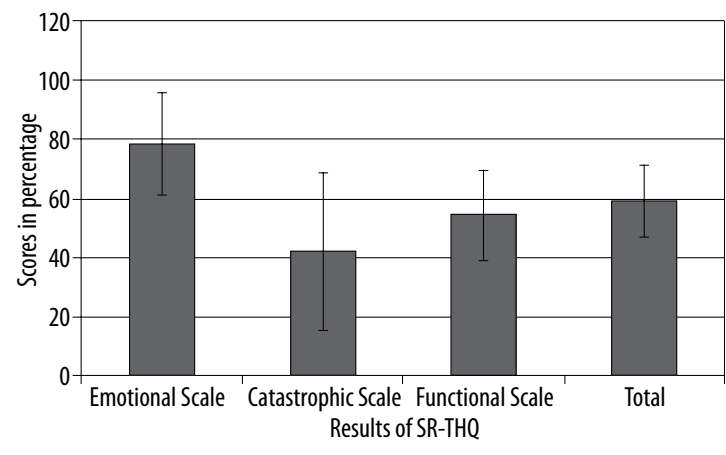

Figure 1. Mean percentage scores on SR-THQ and its subscales in 30 individuals with ANSD

$10 \%$ ( 3 out of 30 ) rated the pitch as mid-frequency (rating of 4-6). In terms of loudness, $26.7 \%$ (8 out of 30 ) rated the loudness of the tinnitus as soft (rating 1-3), 23.3\% (7 out of 30) rated it as loud (rating of 7-10), and 50\% (15 out of 30) rated the loudness as medium (rating of 4-6). In terms of severity, $23.3 \%$ (7 out of 30 ) rated the severity of the tinnitus as mild (rating of 1-3), 33.3\% (10 out of 30 ) rated it as severe (rating of 7-10), and $43.3 \%$ (13 out of 30 ) rated the severity as moderate (rating of 4-6). The results are shown graphically in Figure 2.

\section{Objective tinnitus evaluation}

The results showed that $76 \%$ of individuals ( 19 out of 25 ) had low-pitched tinnitus $(<1000 \mathrm{~Hz})$ and $24 \%$ (6 out of $25)$ had high-pitched tinnitus $(>1000 \mathrm{~Hz})$. Of the 25 participants, 10 individuals (40\%) matched their tinnitus to $250 \mathrm{~Hz}$ or $500 \mathrm{~Hz}, 9$ individuals (36\%) matched it to 750 $\mathrm{Hz}$ or $1000 \mathrm{~Hz}, 3$ individuals (12\%) matched their tinnitus to between $1000 \mathrm{~Hz}$ and $2000 \mathrm{~Hz}$, and the remaining 3 individuals (12\%) matched their tinnitus to $>2000 \mathrm{~Hz}$. The results are shown in Figure 3. The overall mean tinnitus frequency was $1080 \mathrm{~Hz}$ with SD of $965 \mathrm{~Hz}$.

Results showed that the mean matching loudness of the tinnitus was 11.4 dB SL (SD of 4.3). The loudness of the tinnitus was less than $10 \mathrm{~dB}$ SL in $32 \%$ of patients (8 out of 25 ), it was $10-15 \mathrm{~dB}$ SL in $56 \%$ (14 out of 25 ), and $>15 \mathrm{~dB}$ $\mathrm{SL}$ in $12 \%$ ( 3 out of 25 ). The maximum loudness matched did not exceed $25 \mathrm{~dB}$ SL. The results are shown in Figure 4.

An effort was made to analyze the correlation between the matched tinnitus frequencies with the SR-THQ scores using Spearman's rank correlation coefficient. The results showed that there was no correlation $(\rho=0.045, p>0.05)$ between the matched tinnitus frequency and the emotional subscale, a weak negative correlation $(\rho=-0.39, p>0.05)$ between tinnitus frequency and the catastrophic subscale, and good negative correlation $(\rho=-0.62, p<0.05)$ between tinnitus frequency and the functional subscale. In addition, the total SR-THQ score and the tinnitus frequency also showed a good negative correlation $(\rho=-0.64, p<0.05)$. The results are shown in the scatter plot of Figure 5.

It was also attempted to analyze the correlation between the matched tinnitus intensities with the SR-THQ scores using Spearman's rank correlation coefficient. The results showed 


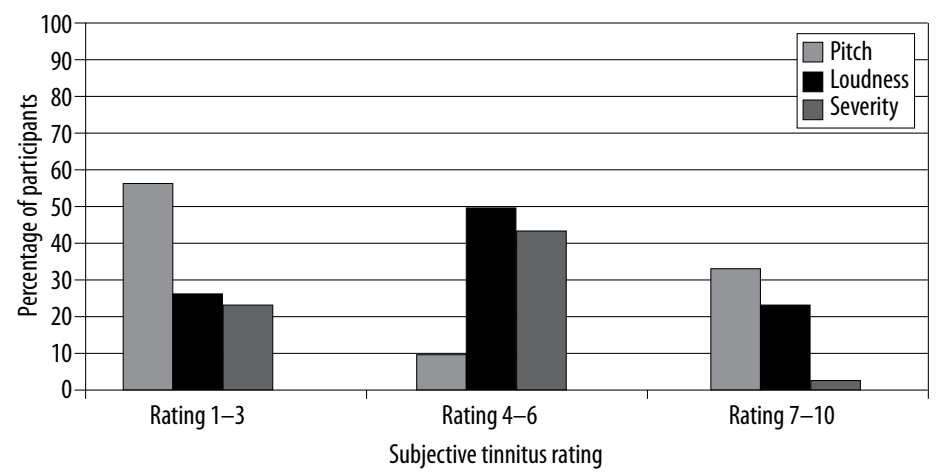

Figure 2. The subjective rating of tinnitus in terms of pitch, loudness, and severity in 30 individuals with ANSD

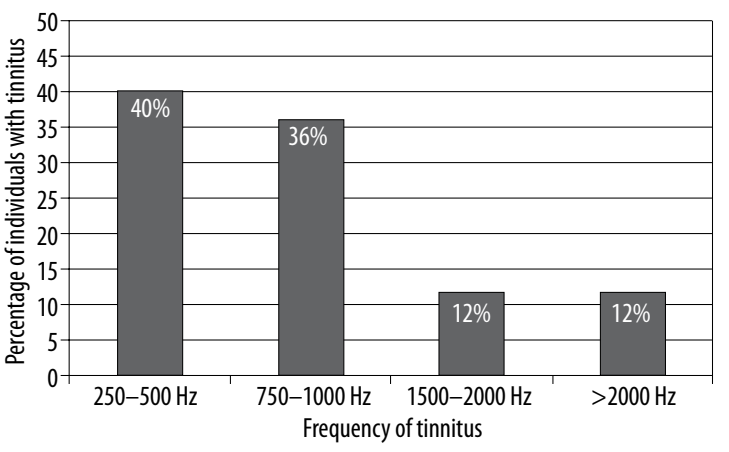

Figure 3. Estimates of tinnitus pitch derived from objective matching in 25 individuals with ANSD

that there was no correlation $(\rho=0.12, p>0.05)$ between the matched tinnitus intensity of loudness and the emotional subscale, a weak negative correlation $(\rho=-0.34, p>0.05)$ between tinnitus loudness and the catastrophic subscale, and a moderate negative correlation $(\rho=-0.53, p>0.05)$ between tinnitus loudness and the functional subscale. In addition, the total SR-THQ score and tinnitus loudness also showed a negative correlation $(\rho=-0.42, p>0.05)$. The results are shown in the scatter plot of Figure 6.

\section{Discussion}

The results of this study show that the overall mean percentage of tinnitus handicap in individuals with ANSD was $59.3 \%$. This suggests they have a significant amount of tinnitus handicap along with the hearing symptoms. The results also show handicap in the functional domain, which suggests that tinnitus in individuals with ANSD can affect routine functioning, a factor which is usually ignored. The functional difficulties seen in individuals with ANSD are usually attributed to hearing loss and difficulty in understanding speech. However, the results of the present study show that tinnitus can also significantly affect how a person functions in daily life. While the psychological aspects of tinnitus are usually ignored, the results of the emotional domain of SR-THQ suggest that individuals with ANSD have a handicap of $78.7 \%$. This shows that persistent tinnitus in individuals with ANSD can lead to emotional problems. The result of the catastrophic domain of SR-THQ suggests that tinnitus was also found to be catastrophic in a few individuals with ANSD. Thus, tinnitus can disrupt sleep, the ability to concentrate at work, or social interactions, and can

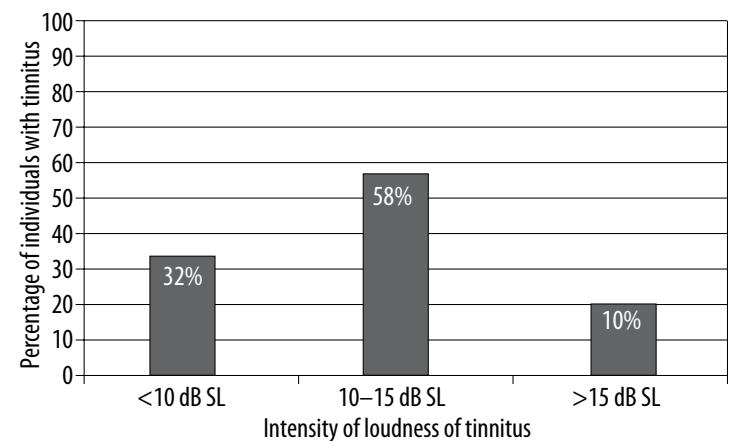

Figure 4. Estimates of tinnitus loudness from objective matchingin 25 individuals with ANSD

cause depression, irritability, frustration, stress, and feelings of helplessness [26].

The results of the study also show that tinnitus perceived subjectively and matched to objective measures occurred at low frequencies in the majority of the patients with ANSD. The most common type of hearing loss seen in patients with ANSD is of the 'peaked' type, with greater loss at low frequencies and a peak at around $2000 \mathrm{~Hz}$ [9]. Low frequency information is usually coded by phase locked responses in Type 1 auditory nerve fibers [27], and individuals with ANSD cannot use phase locking cues to the same extent as normal-hearing listeners due to the asynchronous discharge of auditory nerve fibers [28]. Tinnitus is usually correlated with the frequency of maximal hearing loss. There are models of tinnitus which predict that changes in the processing of neuronal activity occur predominantly in the frequency range of reduced sensory input, which results in increased neuronal activity and/or synchrony in the respective central auditory pathways $[29,30]$.

The results of the study show that there was no correlation between the frequency or loudness of tinnitus and scores on the emotional scale, and only a weak correlation with scores on the catastrophic scale. There was a moderately good negative correlation between the functional scale and tinnitus frequency and loudness. The overall SR-THQ score showed a good negative correlation with tinnitus frequency, and a weak negative correlation with loudness of tinnitus. The results are in agreement with several reports in literature $[18,20,31,32]$ in which no relationship was found between psychophysical measures of pitch or loudness and 

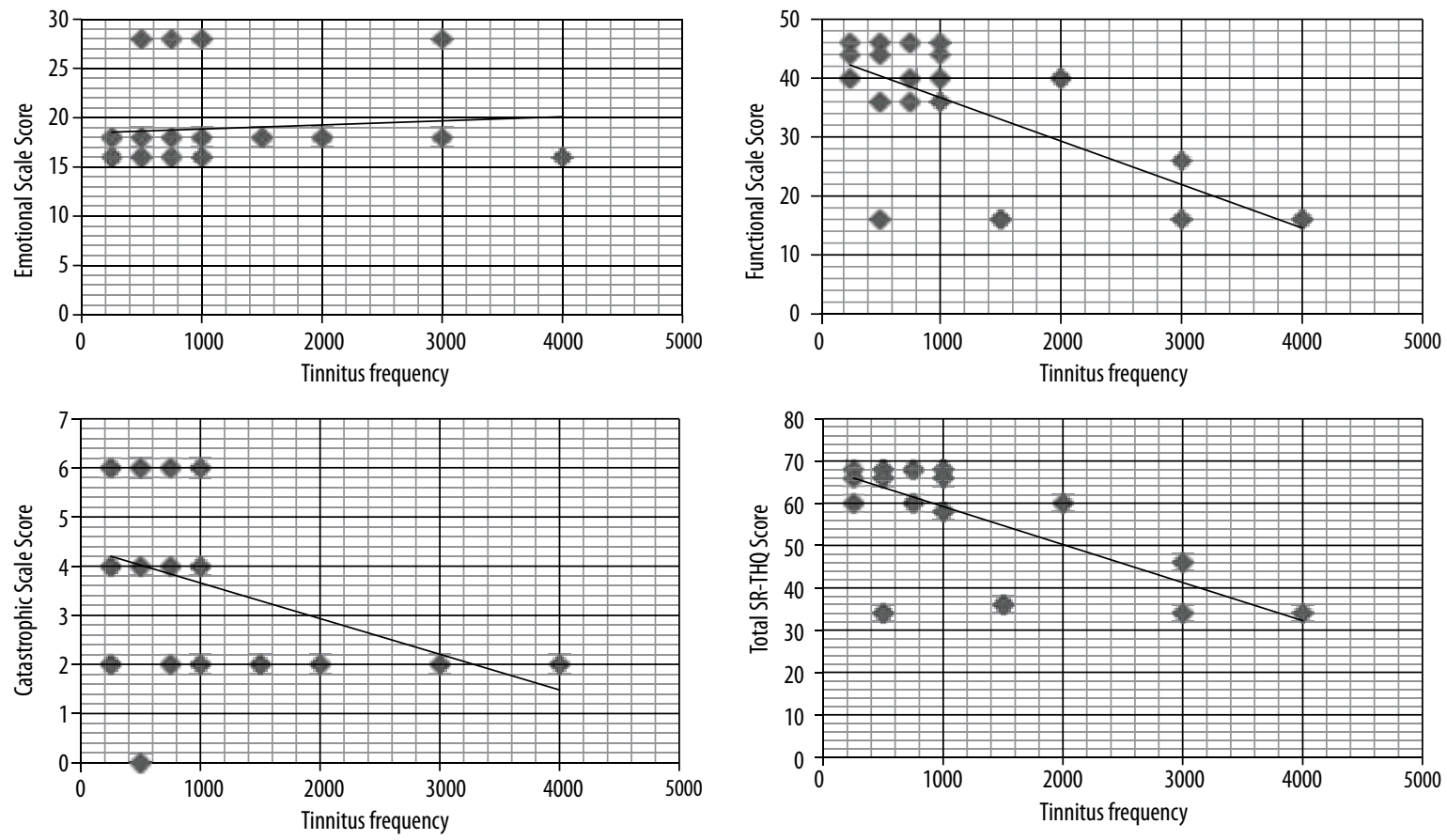

Figure 5. Scatter plots of matched tinnitus frequency with SR-THQ scores on emotional, functional, catastrophic, and total scales
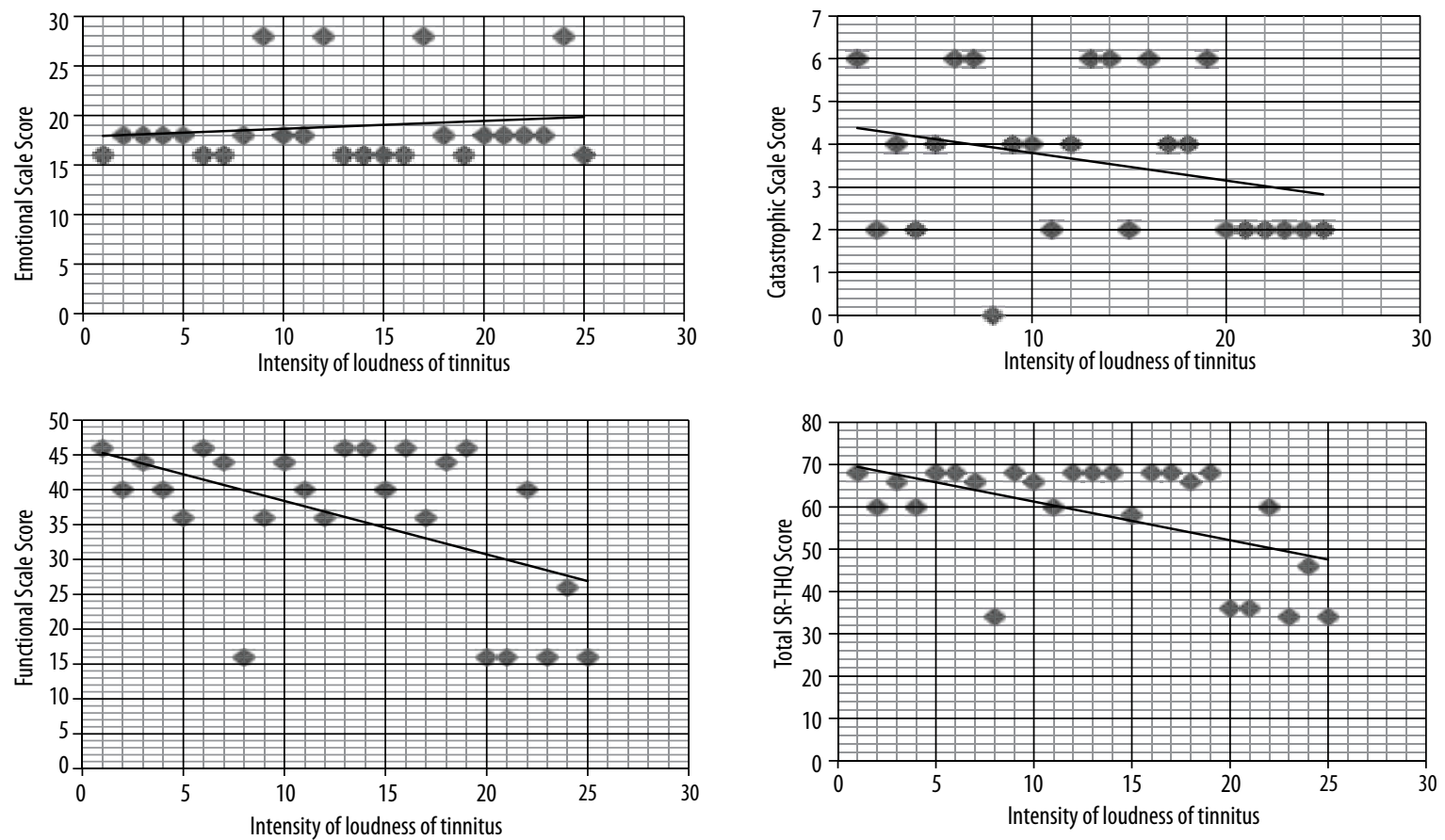

Figure 6. Scatter plots of matched tinnitus loudness with SR-THQ scores on emotional, functional, catastrophic, and total scales

the degree of perceived handicap, as quantified by self-report questionnaires. This lack of correspondence can be explained by cognitive variables, namely somatic attention [31, $33,34]$ and the subject's ability to cope with distress $[35,36]$, both of which relate directly to tinnitus annoyance. Thus, the frequency and intensity of tinnitus may not relate to the perceived handicap, especially on the emotional and catastrophic scales. However, the functional scale scores and the overall SR-THQ scores are weighted towards the low frequencies and the scores reduce as the frequency of tinnitus increases. 


\section{Conclusions}

The present study aimed to determine the handicap caused by tinnitus in individuals with ANSD using a self-report questionnaire. The results show that individuals with ANSD experience a significant tinnitus handicap. The results also show that tinnitus affects how the client functions in daily life, it causes significant emotional problems, and in a few individuals with ANSD it produces catastrophic effects. The reported tinnitus in the majority of individuals with
ANSD was low-pitched, moderately loud, and moderate in severity. The results also showed that there was a weak to moderate negative correlation between some scales of SRTHQ and the matched tinnitus intensity and frequency. Thus, tinnitus causes significant handicap and affects the client's daily life functioning along with emotional problems in individuals with ANSD. Hence, it is important to attend to the symptoms of tinnitus in individuals with ANSD along with the other symptoms and to provide appropriate management.

Appendix A. Self report tinnitus handicap questionnaire (SR-THQ)

\begin{tabular}{|c|c|c|c|c|}
\hline SI. No & Questions & Yes & Sometimes & No \\
\hline 1 & Do you complaint tinnitus as significant problem for you? & & & \\
\hline 2 & Do you have tinnitus or sounds all the time? & & & \\
\hline 3 & Have you noticed changes in the loudness of tinnitus? & & & \\
\hline 4 & Do you feel that you can no longer cope with your tinnitus? \# & & & \\
\hline 5 & Does tinnitus make you feel difficult to relax? & & & \\
\hline 6 & Does tinnitus make you feel irritable? & & & \\
\hline 7 & Does your tinnitus make you feel anxious? * & & & \\
\hline 8 & Does your tinnitus interfere with your job or household responsibilities? * & & & \\
\hline 9 & Does your tinnitus play stress on you? & & & \\
\hline 10 & Do you feel as though you cannot escape tinnitus? & & & \\
\hline 11 & Do you have difficulty understanding speech when you have tinnitus? & & & \\
\hline 12 & $\begin{array}{l}\text { Do you find it difficult to focus your attention away from your tinnitus and on } \\
\text { other things? * }\end{array}$ & & & \\
\hline 13 & Does tinnitus make you uncomfortable to be in quiet? & & & \\
\hline 14 & Does your tinnitus make you feel harder to interact pleasantly with other? \# & & & \\
\hline 15 & Does tinnitus make you feel tired or ill? * & & & \\
\hline 16 & Does tinnitus make you feel depressed? & & & \\
\hline 17 & Because of your tinnitus do you feel frustrated? * & & & \\
\hline 18 & Does tinnitus cause you headache? & & & \\
\hline 19 & Does tinnitus cause you trouble getting to sleep? ${ }^{*}$ & & & \\
\hline 20 & Do you have difficulty in understanding speech in noisy surroundings? & & & \\
\hline 21 & Does your tinnitus make you feel difficult to concentrate? & & & \\
\hline 22 & Do you feel your tinnitus is annoying? & & & \\
\hline 23 & Does tinnitus cause you staying asleep? & & & \\
\hline 24 & Had any medication caused you to experience changes in your tinnitus? & & & \\
\hline 25 & Do you experience pain or plugging in the ear? & & & \\
\hline
\end{tabular}

Not labelled - Functional Scale; ${ }^{*}$ - Emotional scale; ${ }^{*}$ - Catastrophic scale.

\section{References:}

1. Berlin CI, Hood LJ, Morlet T, Wilensky D, Li L, Mattingly KR et al. Multi-site diagnosis and management of 260 patients with auditory neuropathy/dys-synchrony (auditory neuropathy spectrum disorder). Int J Audiol, 2010; 49: 30-43.
2. Berlin C, Hood L, Morlet T, Rose K, Brashears S. Auditory neuropathy/dys-synchrony: diagnosis and management. Ment Retard Dev Disabil Res Rev, 2003; 9: 225-31. 
3. Starr A, Picton TW, Sininger Y, Hood LJ, Berlin CI. Auditory neuropathy. Brain, 1996; 119: 741-53.

4. Deltenre $\mathrm{P}$, Mansbach AL, Bozet $\mathrm{C}$ et al. Auditory neuropathy with preserved cochlear microphonics and secondary loss of otoacoustic emissions. Audiology, 1999; 38: 187-95.

5. Roush P, Frymark T, Venedictov R, Wang B. Audiological management of auditory neuropathy spectrum disorder in children: a systematic review of literature. Am J Audiol, 2011; 20: 159-70.

6. Amatuzzi M, Liberman MC, Northrop C. Selective inner hair cell loss in prematurity: a temporal bone study of infants from a neonatal intensive care unit. J Assoc Res Otolaryngol, 2011; 12(5): 595-604.

7. Nachman, AJ. Retrocochlear hearing loss in infants: a case study of juvenile pilocytic astrocytoma. Int J Audiol, 2012; 51: 640-4.

8. Picton TW. Auditory neuropathy: when time is broke. Chapter 15 in Human Auditory Evoked Potentials. San Diego: Plural Publishing; 2011.

9. Kumar AU, Jayaram M. Prevalence and audiological characteristics in individuals with auditory neuropathy/dys-synchrony. Int J Audiol, 2006; 45: 360-6.

10. Chandan HS, Prabhu PP, Deepthi M. Prevalence and characteristics of tinnitus in individuals with auditory neuropathy spectrum disorder. Hearing, Balance and Communication 2013; 11: 214-7.

11. Prabhu P, Avilala VKY, Manjula P. Predisposing factors in individuals with late onset auditory dys-synchrony. Asia Pacific Journal of Speech language and Hearing, 2012; 15(1): 41-50.

12. Tang, TP, McPherson, B, Yuen KC, Wong, LL, Lee JS. Auditory neuropathy/auditory dys-synchrony in school children with hearing loss: frequency of occurrence. International Journal of Pediatric Otolaryngology, 2004; 168: 175-83.

13. Baguley DM. Mechanism of tinnitus. Br Med Bull, 2002; 63: 195-212.

14. Axelsson A, Ringdahl A. Tinnitus: a study of its prevalence and characteristics. Br J Audiol, 1989; 23: 53-62.

15. Meyerhoff WL, Cooper JC, editors. Tinnitus. Philadelphia: Saunders; 1991.

16. House PR, editor. Personality of the Tinnitus Patient. [CIBA Foundation Symposium 85.] London: Pitman Books; 1981.

17. Sullivan MD, Katon W, Dobie R, Sakai C, Russo J, HarropGriffiths J. Disabling tinnitus: association with affective disorder. Gen Hosp Psychiatry, 1998; 10: 285-91.

18. Kuk FK, Tyler RS, Russell D, Jordan H. The psychometric properties of a tinnitus handicap questionnaire. Ear Hear, 1990; 11: 434-5.

19. Wilson PH, Henry JL, Bowen M, Haralambous G. Tinnitus Reaction Questionnaire: psychometric properties of a measure of distress associated with tinnitus. J Speech Hear Res, 1991; 34: 197-201.
20. Newman CW, Jacobson GP, Spitzer JB. Development of the Tinnitus Handicap Inventory. Arch Otolaryngol Head Neck Surg, 1996; 122: 143-8.

21. Shanbal JS. A self report tinnitus handicap questionnaire (SRTHQ). An independent project submitted to University of Mysore, Mysore 2002.

22. Hallam RS. Manual of the Tinnitus Questionnaire. London: Psychological Corporation; Harcourt-Brace, 1996.

23. Starr A, Sininger $Y$, Pratt $H$. The varieties of auditory neuropathy. J Basic Clin Physiol Pharmacol, 2000; 11: 215-30.

24. Carhart R, Jerger JF. Preferred method for clinical determination of pure-tone thresholds. Journal of Speech and Hearing Disorders, 1959; 24: 330-45.

25. Yathiraj A, Vijayalakshmi CS. Phonemically Balanced Word List in Kannada. Developed in Department of Audiology, All India Institute of Speech and Hearing, Mysore, 2005.

26. Kochkin S, Tyler RS. Tinnitus treatment and the effectiveness of hearing aids: hearing care professional perceptions. Hearing Review, 2008; 15(13): 14-8.

27. Sek A, Moore BCJ. Frequency discrimination as a function of frequency measured in several ways. J Acoust Soc Am, 1995; 97: 2479-86.

28. Zeng FG, Kong YY, Michaleski HJ, Starr A. Perceptual consequences of disrupted auditory nerve activity. J Neurophysiol, 2005; 93: 3050-63.

29. Norena AJ. An integrative model of tinnitus based on a central gain controlling neural sensitivity. Neurosci Biobehav Rev, 2011; 35: 1089-109.

30. Schaette R, Kempter R. Predicting tinnitus pitch from patients' audiograms with a computational model for the development of neuronal hyperactivity. J Neurophysiol, 2009; 101: 3042-52.

31. Newman G, Wharton JA, Jacobson GP. Self-focused and somatic attention in patients with tinnitus. Journal ofthe American Academy of Audiology, 1997; 8(3): 143-9.

32. Newman CW, Wharton JA, Shivapuja BG, Jacobson GP. Relationships among psychoacoustic judgements, speech understanding ability and self-perceived handicap in tinnitus subjects. Audiology, 1994; 33: 47-60.

33. Jastreboff PJ. Phantom auditory perception (tinnitus); mechanisms of generation and perception. Neurosci Res, 1990; 8: $221-54$.

34. Kirsh CA, Blanchard ED, Parnes HY. Psychological characteristics of individuals high and low in their ability to cope with tinnitus. Psychosom Med, 1989; 51: 209-17.

35. Scott B, Lindberg P, Lyttkens L, Melin L. Predictors of tinnitus discomfort, adaptation and subjective loudness of tinnitus. Br J Audiol, 1990; 24: 51-62.

36. Hiller W, Goebel G, Rief W. Reliability of self-rated tinnitus distress and association with psychological symptom patterns. Br J Clin Psychol, 1994; 33: 231-9. 